\title{
'Forming identity through Song': How our songs in worship shape our theological identity: A study of Lutheran hymns and how they shaped German descendent Lutheran congregations
}

\begin{tabular}{|c|c|}
\hline $\begin{array}{l}\text { Author: } \\
\text { Gertrud Töns }\end{array}$ & \\
\hline $\begin{array}{l}\text { Affiliation: } \\
{ }^{1} \text { School of Re } \\
\text { Philosophy a } \\
\text { University of } \\
\text { South Africa }\end{array}$ & $\begin{array}{l}\text { Igion, } \\
\text { d Classics, } \\
\text { KwaZulu-Natal, }\end{array}$ \\
\hline $\begin{array}{l}\text { Corresponde } \\
\text { Gertrud Töns }\end{array}$ & $\begin{array}{l}\text { ice to: } \\
\text { ng }\end{array}$ \\
\hline $\begin{array}{l}\text { Email: } \\
\text { gertrud.tonsi } \\
\text { com }\end{array}$ & g@googlemail. \\
\hline $\begin{array}{l}\text { Postal addre } \\
50 \text { Pat Newso } \\
\text { Epworth, Piet } \\
\text { 3201, South }\end{array}$ & $\begin{array}{l}\text { s: } \\
\text { m Road, } \\
\text { ermartizburg } \\
\text { frica }\end{array}$ \\
\hline $\begin{array}{l}\text { Dates: } \\
\text { Received: } 18 \\
\text { Accepted: } 17 \\
\text { Published: } 06\end{array}$ & $\begin{array}{l}\text { uly } 2012 \\
\text { Jan. } 2013 \\
\text { Sept. } 2013\end{array}$ \\
\hline $\begin{array}{l}\text { How to cite } t \\
\text { Tönsing, G., } 2 \\
\text { identity throu } \\
\text { our songs in } \\
\text { our theologic } \\
\text { study of Luth } \\
\text { and how they } \\
\text { German desc } \\
\text { Lutheran con } \\
\text { HTS Teologies } \\
\text { Theological S } \\
\text { Art. \#1303, } 1 \\
\text { http://dx.doi. } \\
\text { hts.v69i1.130 }\end{array}$ & $\begin{array}{l}\text { is article: } \\
\text { O13, '“Forming } \\
\text { gh Song": How } \\
\text { /orship shape } \\
\text { al identity: A } \\
\text { ran hymns } \\
\text { shaped } \\
\text { endent } \\
\text { regations', } \\
\text { e Studies/ } \\
\text { udies 69(1), } \\
\text { pages. } \\
\text { org/10.4102/ } \\
3\end{array}$ \\
\hline $\begin{array}{l}\text { Copyright: } \\
\text { (C) 2013. The } \\
\text { Licensee: AOS } \\
\text { OpenJournals } \\
\text { is licensed un } \\
\text { Creative Com } \\
\text { Attribution Li }\end{array}$ & $\begin{array}{l}\text { Authors. } \\
\text { IS } \\
\text { This work } \\
\text { der the } \\
\text { nons } \\
\text { ense. }\end{array}$ \\
\hline Read online: & \\
\hline 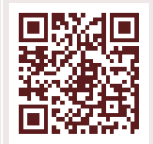 & $\begin{array}{l}\text { Scan this QR } \\
\text { code with your } \\
\text { smart phone or } \\
\text { mobile device } \\
\text { to read online. }\end{array}$ \\
\hline
\end{tabular}

How do songs and Christian hymns shape the identity and theology of Christian communities? How does the identity and theology of a Christian community shape the hymns that are written, sung and collected in song books and hymnals? This article explores these questions from the point of view of the author's community, the German-descendent Lutheran communities in South Africa, and studies their main hymn book, the Lutheran hymnal from Germany (Evangelisches Kirchengesangbuch [EKG]) which was used from the 1950s until the early 1990s in the congregations. It shows up the strengths and the gaps of these hymns which come from a theology with a strong focus on faith and trust, but a rather narrow personal morality, with the social ethics restricted to doing one's Christian duty and praying for the government. Comparing this hymnal to the later hymnal published in 1990, the article shows, that some of the blind spots of one generation can be filled in by the next generation of songwriters.

\section{Introduction}

I am a Lutheran, proud of my musical heritage. Ever since the time of Martin Luther, the hymn book has come a close second for Lutherans in importance, behind the Bible, in shaping our faith and our life. This has definitely been true for me. The hymn book has played an outstanding role in my faith and life development from a young age. But it has been true as well for Lutheran communities in South Africa. I want to focus on the traditional German and mission-descendent communities, and the Lutheran hymns that have been part of their identity. How did the themes and biblical interpretations of their hymns shape their faith and Christian action? You might find that some of the issues discussed in this article played a role not only in the Lutheran congregations but also in other denominations with their singing traditions.

This article was presented as a paper at an academic conference in July 2012 at the University of KwaZulu-Natal (UKZN). It is part of a larger research project into Christian songs and how they function, which forms the basis of a PhD dissertation in the field of Practical Theology and Liturgical studies. Hymnology is a field which one can approach from a church music perspective or from a practical theological perspective. This article has a practical theological approach and focuses on the study of song texts in denominational hymnals. I will look mainly at three hymn books in use in my church: The old German hymnal the Evangelisches Kirchengesangbuch (EKG) of the 1950s, the newer German hymnal of 1994, the Evangelisches Gesangbuch (EG), and the English Lutheran hymnal presently in use, the Australian Lutheran hymnal (LH). ${ }^{1}$

This article follows hymnological convention when it refers to hymnbooks by abbreviation rather than editor. The full details of the books are found in the Bibliography.

\section{The influence of a hymn book}

Some Lutheran hymnologists have compared the relative importance of the Bible and hymnbook with the sun and the moon (Albrecht 1995:97). The hymn book was compared to the moon, reflecting the sun's rays, that is, reflecting biblical teachings. This is a useful picture in some ways, but fairly misleading in others, because although the influence of the Bible seems to be the constant, invariable element in the Christian's faith life, it is not that simple, and on the other hand the hymnbook does not only passively reflect the Bible, but also actively shapes the way the Bible teachings are understood.

1.The Evangelisches Kirchengesangbuch (EKG) that was produced in the 1950 s and reprinted many times, was used in the South African German Lutheran communities well into the 1990s. It was then replaced by the Evangelisches Gesangbuch (EG) 1994. For English services the Australian Lutheran Hymnal of 1973 is still in use. 
The content of the Bible is fixed. But the way we interpret it is not. The way we judge the relative importance of different passages, where we place our emphasis and which texts we practically ignore, changes and shifts with our theology and context. Such changes in theology and biblical interpretations are reflected but also shaped by the hymn book. Shifts in theology change hymn writers' choices of themes and interpretations. New favourite themes and ways to deal with classical Christian questions emerge. Hymns may also be critical comments on popular trends. The new hymns have an impact on the consciousness and understanding of congregations. Some become popular and well used, others are quickly forgotten. Then there are the selectors and the hymnal commissions, who according to their theological understanding make choices about hymns that are selected and left out of normative hymn books. After the new hymnal or song book has been distributed, it is then the pastor and the congregants who determine what is sung and what is left unsung. The question which songs become, and which will remain genuine 'church hymns', accepted and loved as part of a community's identity and expressing its theology, is an immensely complex process (Lieberknecht 1994:11-12). ${ }^{2}$

If we are honest, for most people in the pews, it is the tune more than anything else, which determines whether a song is accepted. The text, which may have more or less theological value, is for many people a secondary consideration. I think we all know examples of popular songs with problematic theology. They survive in spite of attempts of critical theologians to suppress them. ${ }^{3}$ Normally writing new lyrics to the popular tune has a better chance of success than trying to stop the song being sung. ${ }^{4}$ The debate is a serious and important one. I am someone who has experienced for myself - but would also argue it is true in general - that the songs we sing shape our theology much more deeply than the sermons we hear. The relationship between the faith of a community and its singing tradition is a complex one of give and take. It is a relationship alive and fraught with emotion, as can be seen in the debates around music and what should be sung, in almost every congregation in which I have attended services.

This article is part of an ongoing research project into the question of the quality of Christian songs. What makes a song 'work'? What helps it survive into the next generation who probably will have a different taste in music? What

2.Lieberknecht speaks of the history of a song in analogy to a human biography. A song is born, gains an identity, grows in stature and acceptance, and then has to pass certain tests (Bewährungs-Situationen). When the song has demonstrated pass certain tests (Bewahrungs-Situationen). When the song has demonstrated st this point a more responsible 'adult' life begins, where it is chosen at intervals to
codify particular emotional and theological content for congregants. This selection codify particular emotional and theological content for congregants. This selection
is not taken lightly and is a sign that the song has already passed many tests. Then at some stage the song is taken out of the hymnal, 'goes on pension', from where it may still be called on now and again before it dies completely. (Lieberknecht 1994:11-12)

3.There were quite a few years when pastors and church musicians tried to prevent the song Silent night from being sung in church at Christmas time, as they felt the theology was too shallow for public worship (see critique in Albrecht 1995.85). The attempts were unsuccessful and the new German hymnal has included it. (EG 46)

4.There have been many debates about the song Onward Christian soldiers but these put no damper on its popularity. Now Michael Foster has written new lyrics to the tune, Onward Christian pilgrims very fitting to the joyful tune. (WS 285 Complete Anglican Hymns 531). These have the potential of being accepted and supplanting the original text. characteristics in the text and the tune should we look out for when we decide which songs are worth teaching a congregation? In 2007 at a conference I delivered a paper critiquing contemporary praise and worship songs (Tönsing 2008). I conceded that there are great exceptions to the general trends, but argued that in general many of these songs had a shallow, one-sided theology, which focussed on glory to the detriment of the Cross, pretended Christians don't have any problems, ignored the horizontal aspects of Christian life such as responsibility, love and service and concentrated almost exclusively on the exalted Christ, to the exclusion of the human, compassionate, serving and suffering Jesus, not to mention a concern for justice or the well-being of the whole earth.

I still maintain that many of my criticisms of the lyrics of praise and worship music are valid, but the longer I reflected on what I said, the more I realised that much of what I had criticised is true also of my own tradition, indeed of much of Christian theology through the centuries. It is therefore unavoidable, that I should turn the same critical eye on the tradition that shaped me. And this is a good time to do it. The Lutheran Churches are preparing for the 500th Anniversary of the Reformation, and have given each year this decade a theme: We are now in the year celebrating Luther and music.

\section{Brief historical overview}

What are the theological and spiritual trends that shaped Lutheran singing? How did the shifts in theology and spirituality affect Lutheran singing tradition, and what in these trends and shifts has an enduring quality for us today? How did theology and biblical interpretation shape the hymn book, and how did the hymn book in turn shape theology?

Without spending much time on this, I do want to give a very brief overview of the history of Lutheran hymnody ${ }^{5}$ to follow some of these trends and shifts and to consider their longterm effects. I think it is well-known that Luther himself is the founder of our hymn-singing tradition, and that from his time on the Lutheran chorale was a fixed part of Lutheran worship. Luther tried to find talented people to write hymns and metrical psalm paraphrases in German, and when not enough were found, he started writing himself, exhibiting an impressive musical and poetic talent (Rößler 1990:40). ${ }^{6}$ Songs were the primary means by which reformation theology was spread amongst the largely illiterate peasant classes. Songs were used not only to praise but also to preach and teach. This came at a time when music in worship had made a bad name for itself, as far removed from the people and as a hindrance rather than a help in worship. The reformer Zwingli saw music as a hindrance to genuine worship and banned it from the service entirely (Thompson 1961:142). Calvin more realistically, saw it as a powerful vehicle to propel words into the hearts of people - both good words, and bad words (Leith 1981:211). Therefore he decided that

5.The basic subdivision of the eras are taken from the short hymnological history at the back of the new German hymnal EG 956.2-956.6.

6.Luther really established the genre of the chorale. He reworked many texts and also many medieval tunes to make them singable to German texts. EG 956.2 (1). 
music could only be used to imprint scriptural words into people's consciousness and did not allow freely composed hymns as this opened the floodgates to problematic theology.

Luther himself made no such restrictions (even though some hymnologists have argued that he did (Routley 1983:17) ${ }^{7}$, but later church authorities, in the thick of the post-Reformation doctrinal controversies, found themselves agreeing that free compositions were dangerous and opened the door wide to heresies. Of course as staunch Lutheran orthodox officials they would never have admitted to agreeing with Calvin. ${ }^{8}$ They restricted hymn singing in church to the hymns of the bona fide reformers (Albrecht 1995:107). ${ }^{9}$ So there was a canon of accepted hymns, mainly by Luther himself, which became the staple for church services. Fortunately, throughout the ages, people continued to write - and often outside formal worship - these other songs would gain popularity and acceptance, until they were finally taken up into the official hymnals. ${ }^{10}$

This dual stream process has come to be characteristic of Lutheran song tradition. We have an officially sanctioned hymn book which is generally used in services ${ }^{11}$ and often other songbooks or collections are used elsewhere, in youth groups, bible study groups and revival services. These contain songs that are part of contemporary theological and music trends. These contemporary songs are sung in these groups, become popular or are discarded, and also shape the spirituality of those attending. Some of the songs are later taken into the official hymnals, others are rejected as having inferior quality music and problematic, or one-sided theology.

So throughout our history, we have had the watchdogs, the hymnal commissions, which have tried to keep the official hymnals according to orthodox Lutheran theology and good taste in music. Of course they have had no means of control over what is sung in the homes, in youth groups and home fellowships and in revival meetings. This is where in every generation contemporary writers have had their space, and they have taken it with sometimes wonderful, sometimes theologically very problematic results, giving the next

7.Eric Routley has argued that Luther himself established the 'canon' of what should be sung by Lutheran congregations and restricted singing to his 37 hymns. There is no evidence that Luther did this, and indeed evidence that he actively encouraged other writers to produce hymns for example, the letter to Spalatin, asking him for psalm paraphrases (Luther [1523] 1972a:68-69).

8.During Lutheran Orthodoxy the rejection of Calvinism was almost as harsh as the rejection of Catholicism. The Lutheran congregations saw the popularity of the Genevan Psalter which was being used to promote Calvinism and countered it with their own paraphrased psalter, the Psalter by Becker and Schütz. (EG 956.2 [2]).

9.Albrecht mentions that the Hymn book of Lutheran Orthodoxy restricted itself to about 30-40 songs in rural areas where most people were still illiterate. They were supposed to know them off by heart (Albrecht 1995:107). There were probably sung mostly in the cities were more people could read. Hymn books were meant for the lead singers and not generally for the average congregant.

10.A famous example of these private collections was Praxis Pietatis Melica by Johann Crüger that introduced the hymns of Paul Gerhardt and many now well-known tunes by Crüger himself (Albrecht 1995:109).

11.At the moment within my church, the Evangelical Lutheran Church in Southern Africa (N-T) these are the Evangelisches Gesangbuch (EG) of 1990 and the Australian Lutheran Hymnal (LH) from 1973. A reprint of the LH with supplement was issued in 1989 and was bought by some congregations, but not by others who felt that as the main section was not updated, one should wait for a revised edition. Many congregations feel that something new is needed, but there is no consensus on a new official English hymnal. round of hymnal commissioners much to sift, to select from and to discard.

Lutheran orthodoxy had a very clear sense of 'doctrinal correctness' and this more than emotive appeal shaped hymns in the 16th and early 17th century (EG 956.2 [2]). This resulted in some fairly dry teaching texts, as well as militant songs about the preservation of the faith of the church. ${ }^{12}$ The focus was on correct Lutheran teaching. This broke wide open in the Pietist movement, starting in the later 17 th century. This movement focussed on faith experience rather than theological teaching - on a personal emotional relationship with Christ. The movement produced many great songs ${ }^{13}$, but also moved into the opposite extreme of orthodoxy - excessive subjectivity, emotionalism and even hostility to the world. Again, the official guardians of church teaching allowed these songs only slow entry into the official hymnals. Lutheran church music reached its high point during the 18th century. The settings of J.S. Bach to even the drier Lutheran chorales have endeared them to countless people, through the ages. Even today, many young people gain access and a love for our hymns through choir music by Bach.

But the next backlash against emotive music was coming. This time it was the Enlightenment, spreading its message of reason as only criterion of truth, which had its effect on hymns. It rejected all emotionalism, resulting in very dry songs which were little more than appeals to human morality with some allowance made for praise of a creator God. Little has survived from this era (EG 956.4 [2]). ${ }^{14}$ The stark contrast between emotion and subjectivity on the one hand, and dry objectivism on the other is a tension that has shaped Lutheran hymn writing until today, and often manifests itself in the tension between what a congregation wants and loves to sing, and the hymns that are chosen, often for their theological teaching value by pastors. ${ }^{15}$ Lutheran hymns have always been used to teach theology. However too many verses and heavy content can dull even emotive tunes. ${ }^{16}$ The Enlightenment was the low point in hymn writing and Lutheran church music. Many traditional hymns were rewritten to conform to rationalist principles or were no longer sung (Albrecht 1995:114).

In the 19th century a new wave of emotional fervour was released. Traditional hymns discarded during the

12.Many of these songs are no longer sung. A song telling the story about the Reformation and the battle for the soul of the church was still in the EKG (202) but was excluded from the EG: Lobt Gott ihr frommen Christen.

13. Notable names are Joachim Neander (e.g. Praise to the Lord, the Almighty EKG 234, LH 442), Gerhardt Tersteegen (God himself is present EKG 128, LH 501) and Nicholas Graf von Zinzendorf (e.g. Jesus lead thou lead on EKG 274 LH 341).

14.A notable exception are the hymns of Christian Fürchtegott Gellert. The poet Matthias Claudius was a critic of the Enlightenment idolisation of rationality. $\mathrm{He}$ refers to this in his evening song Der Mond ist aufgegangen EKG 368 verses 4 and 5.

15. How much this tension is still felt, is shown by the fact that the Evangelical Church in Germany devoted a whole edition of its liturgical journal Zeitschrift der Gemeinsamen Arbeitsstelle für Gottesdienstliche Fragen to the issue of feeling, sentiment and 'kitsch' in the Sunday Service (Klek 2008:39-43).

16. Many hymns in the EKG have more than 7 verses, 10 is not uncommon. Those of Paul Gerhardt can go up to 13,15 , even 18 verses (EKG 230). In general hymnal commissions have left it up to congregations to make selections and have not cut down hymns, but very seldom are these hymns sung in full. 
Enlightenment were rediscovered, as were the Pietist favourites, and in the midst of missionary fervour a singing tradition developed that was exported to the mission field, translated and adapted: emotive songs of militant faith and enthusiasm to spread the gospel, songs of a fervent love of Jesus. Many of these were collected in the influential songbook Mission Harp. ${ }^{17}$ Mixed in with missionary fervour was also a growing sense of German national identity, even nationalism. Most of these songs were rejected by the hymnal commission of 70 years ago as excessively sentimental or too militant. But they continued to be sung with enthusiasm in groups and services. Some of these songs have now been accepted into the latest German hymnal (Klek 2008:39-47). ${ }^{18}$

The counter movement was again inevitable, and at the beginning of the 20th century, a movement started that rejected the Romantics of the 19th century, rediscovered Reformation hymns and medieval hymns and wrote music in the old medieval church tones and in the style of Gregorian chant or the Genevan psalter. ${ }^{19}$ Many texts were written to old tunes. The 19th century Romanticism was associated with German nationalism and rejected by the poets of the resistance like Bonhoeffer, Klepper and Riethmüller. This movement culminated in the hymn book Evangelisches Kirchengesangbuch (EKG) on which I want to base this study. It is the hymn book I grew up with. It generally rejected the songs of the 19th century, only 14 of its 400 hymns are from the 19th century ${ }^{20}$, and it purged the hymnal of excessively emotive tunes.

The extremes of the pendulum of Lutheran hymnal history gives some substance to the prejudice, that whatever Germans do, good or bad, they tend to do thoroughly. The other Lutheran traditions such as the Scandinavians and later the Americans and Australians, steered clear of these extreme swings, but to look into this goes beyond the scope of this study. I will stay with my own tradition, which is the South African German Lutheran community.

Our Lutheran congregations in South Africa, particularly in KwaZulu-Natal, are largely a product of the 19th century missionary movement and were deeply influenced by the spirituality behind the Mission Harp songs. They were also a product of the strong German nationalism of the 19th and early 20th century and the militancy and triumphalism in some of its music. ${ }^{21}$ Most of the German Lutheran

17.The Missionsharfe came out in two editions. The Kleine (small) Missionsharfe, (1st edn. 1852) which was a book in two-part harmony for groups and mission festivals. The Große (large) Missionsharfe was in four part settings for choirs. There were The Große (large) Missionsharfe was in four part settings for choirs. There were
many editions and it was reprinted until well into the 20 th century. My edition of the Kleine Missionsharfe is the 79th Edition of 1919 and of the Große Missionsharfe the edition of 1925

18. For example the very popular and translated Take now my hands and lead me (EG 376, KMH 145, LH 301) and Harre meine Seele (EG 593, KMH 72). A critical look at this process of 'Rehabilitation' is given by Klek (2008).

19.New tunes in the EKG in old styles, that is, without fixed rhythm or bar lines, or conventional major or minor keys are for example 13 (1937), 14 (1939), 35 (1939), $162 ; 225$ (1938), 351 (1949).

20.Of these 14 Songs, 2 have different tunes in the KMH than in the EKG and 12 are not found in the KMH.

21.Two examples from KMH: Wer will ein Streiter Jesu sein? (Who will be a fighter for Jesus?) (KMH 99), a cry to follow Jesus into battle, and Wir reichen uns zum Bunde die treue Bruderhand (We hold out brotherly hands in covenant promise) (KMH 164) which strengthens community bonds before the 'hour of the fight arrives.' congregations were either unaware or supportive of the rise of National Socialism and they transferred this allegiance with relative ease to the Afrikaner nationalists after the 1948 elections. How this is reflected in the 'non-official' singing tradition would be a fascinating object for another study, but goes beyond the scope of this one..$^{22}$

Nevertheless the congregations were committed Lutherans with loyalty to Germany, and thus, although there was little understanding of the post-war shift in consciousness and theology in Germany, most congregations accepted the post-Second World War hymnal which was brought out in Germany. Many continued to sing their favourites from the Mission Harp, emotive songs of a fervent, personal faith and of course the contemporary songs of various styles that came out. But in the church services, the strong proclamatory songs of Lutheran faith were still the standard.

\section{The hymns of the Evangelisches Kirchengesangbuch}

This article focuses on these hymns, hymns of Lutheran tradition and Lutheran identity, which remained the staple in Lutheran services throughout the missionary period, which had been translated into other languages throughout the mission fields and which unite Lutherans in song when they come together. I have taken as basis of this study the 394 hymns from the German EKG. Of course not all these have been translated. But a great many have, and they give the study a clear limit and focus. I will quote the English translations if they are fairly close to the German. I have looked at themes, theological trends and most particularly, asked the question: How do these hymns compare to the points I critiqued in my article on Worship songs? (Tönsing 2008). How much 'horizontal focus' do these hymns have? Where do they focus on the healing and compassionate ministry of the human Jesus, and on Christian love and responsibility? I fully admit that I have taken a much wider sample than in my study on worship songs, and had I taken only the top 50, the results might have been pretty dismal. But I have now looked at the full spread of this now 60-year-old collection, and obtained a sense of the themes and the gaps.

Authorised denominational hymnals normally have a wide spread of themes. They cover the themes of major church festivals, worship and sacraments, stages of life and the life of faith of a Christian. They represent the best of what was produced in countless generations of Christian hymn singing, and (if they contain Psalm texts) of believers much further back. Because each new generation has its own emphasis and theological bias, they are able to be much wider and more thorough in their spread of emphases than any contemporary songbook is able to be. Nevertheless, each hymn book still has its blind spots and limitations, which each new generation of songwriters is challenged to rectify.

22.The details in this and the next paragraph come from personal experience and memory and have not been researched or substantiated by interviews or surveys. 


\section{Praise and Thanksgiving}

Songs of praise and thanksgiving are the backbone of any hymnal and any contemporary song book. And the EKG is no exception. However compared to many other hymnals the section is relatively small, only 13 songs out of 394 and only a handful of them have exuberant, emotive tunes (EKG 226-238). ${ }^{23}$ (Of course there are songs in other sections which have a tone of thanksgiving). ${ }^{24}$ It fits into the picture of Lutheran spirituality as being relatively serious and focussed on the Cross. This alone makes understandable the desire by many congregants in that time to supplement the EKG, with more emotive songs. On the other hand, these are songs of praise that take seriously the reality of human suffering and difficulties and still find words to praise God through it, much as the Psalm writers do. I have critiqued worship songs saying that their praise is often shallow, pretending that Christians have overcome all problems through faith. This is in no way applicable to the Songs of Praise of the EKG. Fairly typical of this is the hymn:
In You is gladness in all our sadness
In You is gladness
in all our sadness,
Jesus, sunshine of my soul.
By You are given
blessings from heaven.
You're the one who makes us whole.
Our hearts You've woken,
our bonds You've broken,
trusting You surely
we build securely.
We stand forever:
Alleluia! (EKG 288 transl. WS 350) ${ }^{25}$

Luther's own hymns have the tendency to be didactic. But he does have some exuberant notes of praise in his hymns, most noteworthy the first verse of Dear Christians one and all rejoice (EKG 239) and his Pentecost hymn Come Spirit of God (EKG 98).

\section{Adoration}

Songs of adoration simply express love of God or Christ and appreciation of who God is and his (or her) attributes. This is of course where worship songs have their strength, and where the EKG has a big gap. Suppressing emotive songs also meant suppressing adoration of God. Hymns praised and thanked and taught about God and human sin and salvation, but left little space for the human need for expressions of the personal faith relationship and what it means to the believer. Having grown up in a tradition that frowned upon such songs, I have grown to appreciate the need for them and the need to find such songs that express such sentiments well, but without being too shallow and sentimental. Both worship songs today and the emotive songs of the missionary and Pietist movement

23.For example a praise hymn by Paul Gerhardt 232 is set in C minor, and the tune for 227 is used also for a prayerfully reflective hymn for New Year's Eve.

24.For example the paraphrases of Psalm 146, EKG 197 and 198 (see later discussion), several morning hymns and some under 'The Church' (206 and 214) and 'Christian Life' $^{\prime}(249,269)$.

25.Johann Lindemann. The translation is composite based on H. Proeve (LH 386), slightly modernised and smoothed by myself. have a whole range of such songs of adoration, those that do it well, and those whose lyrics are no more than a play on emotions with little theological substance. Of course, the question when something is 'too sentimental' is a matter of opinion. ${ }^{26}$

To understand the current friction in Lutheran congregations between traditionalists and the proponents of contemporary worship music one needs to understand something of the forces that shaped Lutheran tradition. I have found that choosing songs which are emotive songs of adoration with some solid theological substance is the key element in breaking down the sometimes acrimonious divisions between these two groups. ${ }^{27}$

Whilst the element of adoration is rare in the EKG there are examples where it is done well. One poet who straddles the divide is the well-known hymn writer Paul Gerhardt, who was a convinced Lutheran Orthodox theologian, but also a forerunner of the Pietist movement, with a very personal approach in his hymns. His expressions of intimate closeness to God are firm favourites in the EKG such as his line: 'Lord, my life and joy forever, thou art mine, I am thine, nothing can us sever' (EKG 297 v. 11, LH 413 v. 5).

The Reformation hymns which became canon in Lutheran orthodoxy are largely devoid of elements of adoration. Luther himself has moments which are more emotionally expressive, for example in his Pentecost hymn and in his Christmas hymn for children:

$O$ dearest Jesus, child so blessed, prepare a bed, that you may rest, a holy shrine within my heart that You and I need never part. (EKG 16 v. 13, WS 16 v. 5) ${ }^{28}$

But it was the proclamatory and didactic tone of the Reformation hymns that set the standard for Lutheran hymns, one could say until today.

\section{Consciousness of sin or Confession}

Lutheran theology has a strong awareness of, and focus on human frailty and brokenness. This is a strength, but can also become a weakness if it is taken to extremes. In spite of the Lutheran proclamation of salvation by grace through faith, in some hymns it can seem as though sin is so serious, that salvation is still questionable and something needing to be pleaded for, rather than trusted in. ${ }^{29}$

Also, in spite of the fact that many hymns speak in general about sin in the generic sense of separation from God and not doing his will, there are very few hymns, where human

26. A Pietist classic by Gerhard Tersteegen is Ich bete an die Macht der Liebe (O I adore God's loving power) (KMH 7) which in spite of its tremendous popularity was not included in the EG. It has an exclusive, strongly emotional focus on the love relationship between Jesus and the individual. Some people strongly lamented its exclusion.

27. A very good example of this is Graham Kendrick's Knowing you, Jesus (WS 265, SF II 646). In my own translation of Tersteegen"s $O$ I adore I have tried to include more theological content, while keeping the element of emotive adoration (WS 279).

28.Translation composite based on ELW 268.

29.An example is a seldom sung hymn Ach Gott und Herr (EKG 168), 'O God and Lord, how great and heavy are my sins. There is no one who can help in this world .... It acknowledges that Christ has paid the price, but prays that I may not 'forfeit my salvation' (free translation). 
sin and failings are spelt out more concretely. In common with much of Christian theology there are references to 'fleshly lusts and earthly desires' and a failure to keep the commandments. There are mentions of 'false teachings' (EKG 177) and 'hypocrisy' (EKG 41). In a few cases mention is made of greed and selfishness or envy (EKG 105, 346) but relatively little mention of how our selfish actions sometimes harm or hurt our neighbours. Many hymns have been shaped by eras of war and conflict in Germany, not least by the Thirty Years' War in Germany - the time in which Paul Gerhardt grew up. But although many hymns ask for peace or God's protection during war, and see war as an evil, there is little recognition of human sin and selfishness as the cause of war and destruction. A notable exception here is Paul Gerhardt's hymn of thanksgiving for the end of the Thirty Years' War, which has a strong notion of repentance for the sins that unleashed God's wrath in war, and a call to preserve the peace (EKG 392). ${ }^{30}$ This very contextual hymn was not translated, and was not often sung, but made a comeback in Germany in the years after the Second World War, where the tone of repentance was again very fitting, for this reason it was included in the EKG. This example is of course a reminder of the fact that the more concrete and contextual songs are, the less likely they are to survive into the next generation which has different problems and questions. And critical, prophetic songs are less likely to gain a foothold in popular consciousness. The above-mentioned hymn was sung regularly soon after the Second World War, then again fell into disuse and was excluded from the present hymnal.

Luther's own hymns speak a lot of repentance and sin. Concrete sins mentioned are usually false teachings (EKG 177), hating God's will and trying to redeem oneself rather than relying on God (EKG 195, 239), that is, 'religious' sins rather than social sins. This did set the tone for Lutheran hymn writing.

\section{The Cross}

Luther called his own theology a 'theology of the Cross' rather than a 'theology of glory' and this has been characteristic of Lutheran spirituality and also of Lutheran hymnals (Luther [1518] 1957:40). ${ }^{31}$ Songs about the Passion of Christ form a large section of the hymnal (21 hymns, the same number as hymns for Christmas) and quite a few other sections contain references to the Cross. The Cross is linked directly with the sin of the individual and God's gift of forgiveness and salvation of the sinner (EKG 54,57). Contemplating the Cross leads to repentance (example $64 \mathrm{v} .4-7,67 \mathrm{v} .3$ ). Jesus' pain is described in vivid detail to remind the believer what the cost of salvation has been (EKG 56, 60 v. 2, 63 v. 1-3). The Cross is seen as a source of comfort in affliction and in the face of death (EKG 63 vv. 9-10). However it happens relatively seldom that the Cross is seen in relation to the pain and suffering of others, or that we see Christ's Cross in the pain of the world. Of Paul Gerhardt's three Passion hymns two 30. Gott Lob, nun ist erschollen das edle Fried- und Freudenwort.

31.Luther uses these terms in the Heidelberg disputation of 1518. It goes beyond the scope of this article to discuss the precise meaning Luther gives to these terms, and whether popular Lutheran understanding of the terms is the same as his. Here and whether popular Lutheran understanding of the terms is the same as his. Here
it simply is taken to mean that in Lutheran spirituality the Passion is given greater it simply is taken to mean that in Lutheran spirituality the Passion is given
weight than texts of power, glory and human transformation by the spirit. speak of personal sin and my responsibility for Christ's death (EKG 63, 64). The third speaks of the 'Lamb carrying the sins of the world' (EKG 62). Considering how central this ancient Christian term for Christ is, it is sobering to see how little the 'salvation of the world' features in the hymns. There are songs which speak in the plural, but meant is the Christian congregation, not the world. The world is seen as the enemy, responsible in part for the crucifixion. One hymn includes the prayer: 'Through your Cross, help us to crucify the flesh and the world' (EKG 66). There are however some examples where the sign of love of Christ in his death inspires the hymn writer to pledge to show love to his neighbour and serve others in the world (EKG 54,61).

Interestingly, Luther himself wrote no passion hymn but only an Easter hymn, but Christ's suffering is a theme in several of his hymns, most notably his communion hymns (EKG 154, 163). The meaning is restricted to personal salvation.

\section{Comfort in affliction}

With 28 hymns in the section 'Trust in God, Cross and Comfort' this aspect is probably the Lutheran hymnal's greatest strength. Lutheran spirituality takes suffering seriously as a fact of life. Nowhere is suffering seen as rooted in unbelief, whilst there are places where it is seen as punishment for sin, these are normally in the context of confession, (EKG 168 v. 4, 232 v. 8) or where it is entirely appropriate, such as the already-mentioned song about the destruction of war (EKG 392). In several places suffering is seen as a test of faith (EKG 294, 298), but more often than not, suffering is simply part of the world as it happens to be (EKG 306). The world is seen as a vale of tears, and we just need to continue to trust in God, and walk through it as a preparation for heaven which is very different (EKG 326). Here the spirituality is similar to Psalm 23 which does not problematise the valleys, but simply accepts them as part of life, through which we walk with God at our side. The attitude of Job in the beginning of the book, that God who gives may also take away (Job 1:21), also underlies many of the hymns (EKG 297). These wonderful hymns have comforted thousands of people in difficulties, in illness, on deathbeds. They have demonstrated their power to comfort, and are even more powerful if the singer knows something of the background of the writers. Many Lutherans know at least in broad outlines some of the details of the life of Paul Gerhardt, who lived through the Thirty Years' War, lost his parents early, and later four children, and gave up his pastor's post because he did not wish to compromise his Lutheran confession. Many other writers have difficult biographies, for example, Georg Neumark who lost everything in a robbery, and spent a time of poverty until he gained a job as teacher. And of course Luther himself, persecuted by the church, in danger of his life. Knowing that the person who is writing the words of comfort genuinely knows what suffering is, gives the words more power.

Nevertheless one can criticise that little space is given to lament and resistance. The attitude of humble submission 
under the hand of the Almighty God can become an intolerable burden for Christians if there is no space for the lament to God and even the space to resist the causes of the suffering. There are muted tones of this in the paraphrases of Psalm s ${ }^{32}$, but a lot more low-key than the Psalms themselves. In general paraphrases of Psalms have not only Christianised but also blunted the power of many of the Hebrew psalms. In general the Psalms are stronger in their power to comfort in their original wording.

\section{Resurrection, New life}

There are fewer Easter hymns than Passion hymns in the EKG (15 against 21), and in general Easter themes play a far smaller role in the rest of the hymn book than references to the Cross. This has its roots in Luther's critique of 'theologies of glory', which ignore the Cross (Luther [1518] 1957:40), also in the difficult situations many Lutheran hymn writers found themselves, and in general with the more serious, penitential Lutheran spirituality. Whilst some Easter themes are found in the section 'Death and Eternity' (EKG 330), there are surprisingly little and even here more comfort seems to be drawn from Jesus' death than from his resurrection.

The Easter hymns themselves tell the Easter story ${ }^{33}$, proclaim that Christ is alive, and speak of a hope beyond death. There are images of the cosmic battle of good against evil, often using the image of the serpent, or the battle of life against death and a proclamation of the triumph of life and the Good (examples: EKG 83 v. 2, 4, 86, 87 v. 2). However there is relatively little reflection about what implications this gift of new life has for our time on this earth. Whilst there is a sense in some songs that the 'world' has been saved and set free ${ }^{34}$, the 'world' is still largely seen as part of the force that held Jesus captive in death (EKG $85 \mathrm{v}$. 4) which has been overcome, allowing us entry into the life beyond (EKG 86 vv. 5-8). Gellert writes that Jesus lives and this means he has dominion over the world (EKG 89). Nikolaus Hermann writes that the sun, earth and all creatures who had been groaning, all rejoice that the 'prince of this world' has been defeated (EKG 80). This phrase, borrowed from Luther, refers to Satan. The 'world' is part of the problem and is in need of redemption.

Luther's Easter hymn Christ Jesus lay in death's strong bands (LH 89, EKG 76) paints the picture of the cosmic battle to free people held captive by death. Jesus' death and Resurrection took away death's sting and life was victorious over death.

\section{Spiritual warfare}

In my experience, spiritual warfare is not a theme that features a lot in Lutheran preaching, or if it does in fairly muted ways. But it covers quite a large part of the hymn book. Militant language comes down from those days when Lutherans 32.An example is Luther's paraphrase of Psalm 12 which has tones of lament EKG 177.

33. Hymn 78 is a dialogue between the women and the angels at the empty tomb. 79 is a simplified paraphrase of the Easter story, which states that fact of resurrection and the words of the angel only.

34.For example in the hymn Christ is arisen EKG 75, literally: 'If he had not arisen, the world would have perished ...', also quoted in 78 verse 2 as the phrase comes from a pre-Reformation Latin hymn. were a persecuted minority, in many a Reformation hymn ${ }^{35}$, but also from the times of Lutheran orthodoxy, when the church tried to defend the 'true' Lutheran faith against those who preached 'dangerous heresies' ${ }^{36}$ Luther's hymn $A$ mighty fortress (EKG 201) begins this trend and it has been called the 'battle hymn of the Reformation' ${ }^{37}$ For Lutherans it symbolises a militant Luther who stood up against the might of Pope and Emperor, although this probably happened with a lot more fear and trembling than the popular myth allows. The hymn dates to 1528 , quite a whilst after the main confrontations with the authorities, and was probably written in the context of personal struggles and afflictions (Rößler 1990:44). ${ }^{38}$ Nevertheless this hymn has remained the mark of Lutheran identity, so it merits a closer look. I am basing my comments on the German original and will correlate these with three different translations: the translation of the American Lutheran hymnal, that of the Australian Lutheran hymnal and my own composite and revised translation.

The hymn is based on Psalm 46 with its central verse: 'The LORD Almighty is with us, the God of Jacob is our fortress' (Ps 46:7; 11). Finding one's security in God in a time of affliction and pressure is a wonderful assurance. Of course, such a message can quickly switch and become ideology, if it comes to mean: God is with us, exclusively and not with the others. He is on our side against the others. Something similar happened in biblical times when the 'God is with us' of Psalm 46 became the ideology that Jerusalem was invincible (Jr 7:115). The battle hymn of the Reformation and the person of Luther himself have been used in all kinds of ideological and problematic ways, giving critical Lutherans a rather broken relationship with it. However I know from experience that in the late 1980s, at the time when there was increasing pressure on people critical of apartheid, this hymn gained a new deep meaning for us as expressing our experience in very many ways.

Following the translation closest to the German (LH 195) the first lines read:

A mighty fortress is our God, a trusty shield and weapon.

Our faithful helper in all need, our stay whate'er may happen.

The translation that I have followed in my own collection leaves out the weapon and concentrates on the shield:

A mighty fortress is our God, a shield that will not fail us. (WS 355)

This indicates an age-old problem, whether one needs to remain literally true to the original in a translation, or whether freedoms are permitted which will also translate a hymn into the new time in which it is sung, knowing the problematic history of ideological wars and struggles, justified by verses

35.EKG 193 by Justus Jonas 1524, 204 by Ambrosius Blaurer 1561, 389 by Wolfgang Capito 1523.

36.EKG 209 by Johann Heermann 1630, 211 by Jakob Fabricius 1632, 212 by Matthäus Apelles von Löwenstein 1644.

37.This hymn exists in many translations and is included in the hymnals of countless denominations, even contemporary songbooks Mission Praise and Songs of Fellowship. LBW 228/229, LH 195 'A safe stronghold our God is still' MP 2 SF 25.

38.Martin Rößler places it in the context of the outbreak of the bubonic plague and Luther's personal health problems and struggles with depression and despair on hearing of Lutherans being martyred. 
such as these. Usually hymnal commissions do take such freedoms, though cautiously. I have not done research on the use of this hymn in Germany's conflict-ridden history, but knowing that Luther was misused for Nationalist ideology, I can hardly imagine that his hymn would not have been used for militant and propaganda purposes. So I feel comfortable in keeping the shield and discarding the weapon.

I continue with the composite translation in my collection:

$$
\begin{aligned}
& \text { The old evil foe, } \\
& \text { now means deadly woe. } \\
& \text { With cunning and might } \\
& \text { he arms himself to fight. } \\
& \text { On earth he has no equal. }
\end{aligned}
$$

2. No strength of ours can match his might!

We would be lost, rejected.

But now the right man comes to fight,

by God himself elected.

And who may this be?

Christ Jesus is He.

The mighty God's son

and with the Father one.

He holds the field for ever. (WS 355)

It must be noted that in spite of my criticism, Luther is consistent in this hymn in making the battle a spiritual battle between Christ and Satan, and not a physical battle between us and our foes here on earth. The believer is under attack, the foe is 'eager to devour us', (v. 3) and in the end may even rob the believer of 'goods, fame, child and wife,' (v. 4) but there is no physical need to go out and annihilate the enemy, because Christ fights for us. To problematise Luther's own stand on the use of violence and political resistance obviously goes beyond the scope of this article.

The Australian Lutheran hymnal has 14 hymns under the section 'The Church militant', six of these are translations of hymns still in the EKG, of which three are by Luther himself.

Whilst most of the hymns speak of spiritual warfare in fairly general terms, the most militant of the hymns is a war cry to follow Jesus into battle and contains the hard-hitting line: 'a coward he who will not heed, when his commander takes the lead' (LH 336, EKG 256). But overall the hymn uses more the imagery of taking up the Cross and following Christ than of military warfare.

\section{Fruits of the Spirit}

When searching the EKG for references to Christian love and responsibility, I saw that the first place it gets a solid mention is in the section on Pentecost hymns. Most Lutherans are not charismatic or Pentecostal. We do not expect supernatural gifts from the Holy Spirit, and most of the year we do not speak much of the Spirit. But when we do, it is in the context of the hope and prayer that our faith in Christ may be strengthened, that the community may be drawn together and that believer's may grow in love and be strengthened for service in the world.

In most Pentecost hymns the spirit is seen as a gift which results in the fruits of faith and love, which draws us closer to the neighbour and makes the church a united community. This is either proclaimed or prayed for. In these hymns, more than in most others, it is presupposed that faith has consequences in our daily life and that Christian responsibility extends into the world.

One example here is Luther's exuberantly joyful Pentecost hymn:

Come, Spirit of God, mighty Lord,

may all Your grace now be outpoured

on each believer's mind and heart,

Your fervent love to them impart.

Lord, by the brightness of Your light

in holy faith Your church unite

from every land and every tongue.

For this Your praise, O Lord,

our God, be sung.

Alleluia! Alleluia! (EKG 98) ${ }^{39}$

And also another verse from Paul Gerhardt, one of my personal favourites:

Lord, in Your hands You carry

the whole world vast and wide.

You change the hearts of people,

You are their help and guide.

In every time and place

let old divisions perish,

that we may love and cherish

each other through Your grace.

(EKG 105 v. 8$)^{40}$

In this section of the hymnal there are some really great texts. Unfortunately they are usually sung only on Pentecost Sunday, one day a year! A greater focus on the Holy Spirit throughout the year would do the Lutherans some good.

\section{Following Jesus, Being sent out, and the Ministry of the human Jesus}

Being called to follow Jesus, or being sent out into the world, are related concepts in Christian theology although they are treated in different ways.

Following Jesus and taking up the Cross in the hymns of the EKG has the connotation of suffering, of forsaking earthly priorities, of going through the world, turning our eyes from temptation and single-mindedly having one's eyes fixed on Christ. When we follow Christ, he will show us how to live and how to 'flee and shun whatever may be harmful' $(E K G ~ 256)^{41}$ in order to remain pure and to follow Christ on the way to heaven. The idea of turning away from the world occurs repeatedly (e.g. EKG 213, 252, 272). This goes against Luther's own notion that people will remain sinful, and should be more concerned with service in the world than with remaining sinless (Luther [1521] 1963:282). ${ }^{42}$ The element of service appears very little in these hymns, even less the idea of following Jesus to those people he went to, that is, the poor and the outcasts.

39.Translation composite in WS 68, Tönsing (based on Richard Massie) LH 121.

40.Translation G. Tönsing in WS 72 based on C. Winkworth LH 130.

41.Ich bin der Weg, ich weise wohl, wie man wahrhaftig wandeln soll. Ich zeig euch das, was schädlich ist, zu fliehen und zu meiden/und euer Herz von arger List zu rein'gen und zu scheiden ... (EKG 256 v. 2-3).

42.In his letter to Melanchton (Letter no 91, 1521:282) he writes: 'Be a sinner, and let your sins be strong, but let your trust in Christ be stronger, and rejoice in Christ who is the victor over sin, death, and the world.' He expounds on Christian service in On the freedom of the Christian (Luther [1520] 1972b:327-378). 
The songs which use the theme of being sent out are less blinkered, but still fairly one-sided. The world is in view, but in general the mission is seen as evangelism only, as spreading the word, rather than as spreading love through acts of service. Notable exceptions are the community songs of the Moravian tradition (e.g. Herz und Herz by Zinzendorf EKG 217) which enriched the Lutheran singing tradition.

There are very few places where the ministry of the human Jesus comes into the hymns. In EKG 245 there is a short reference to the words: 'my yoke is easy and my burden is light' (Mt 11:30). In hymn EKG 259 there is a positive reference to Mary sitting at the feet of Jesus, listening to Jesus the teacher (Lk 10:42). Several references speak about Jesus as the Good Shepherd (EKG 151, 268 and others). However in general, besides the stories of Jesus' birth, suffering, death, resurrection and ascension, the content of the gospels find little echo in the hymnal. This is a major lamentable gap.

\section{Christian love and responsibility}

Most other songs about Christian love and responsibility are found under the section: 'Christian Faith, Christian Life', and several under 'Morning songs', praying for the day ahead and its tasks. However it is disappointing to see how abstract and often dryly it is dealt with. The passion and poetic quality that is found in the songs where they speak about faith and the assurance of salvation is not reached in the songs or verses that speak about Christian love and service. In some songs it is almost as if it is mentioned out of a sense of duty, rather than conviction.

A rather typical example is the classic reformation hymn about justification by faith by Paul Speratus Salvation unto us has come (EKG 242, LH 324). In the original there are twelve verses which teach the basic dogma of justification by faith fairly dry, but definitely not the worst of what was out there. Of these twelve verses, one half a verse speaks of the fruit of this faith being love and service to the neighbour, and another few phrases stress that - although works are a sign of faith, they do not justify you before God.

Here in the translation of the Australian Lutheran hymnal:

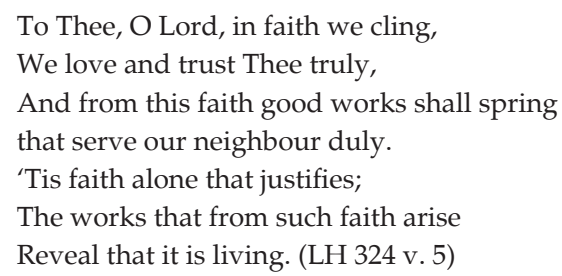

This is fairly dry-rhymed dogmatics, but is repeated in more or less poetically powerful ways in several other hymns (EKG 247 v. 2, 269 v. 7, 271 v. 8). The reasons for faith are proclaimed in glowing terms. That something should follow faith is mentioned, but not stressed with any emphasis, out of a fear that one might be promoting justification by works. Love and service is almost an optional extra, something that should follow automatically, but where one need not be too concerned if it does not, as that merely proves the point that we are sinners.
This is an area where I am highly critical of my own tradition, which, although it has changed a lot in the last 20 years, still has the tendency to see acts of mercy and diaconical work particularly aimed at people outside the congregation - as not being part of the 'core business' of the church, even less any prophetic ministry.

Fortunately even in the EKG, but much more in the new German hymnal, there are hymns that speak with passion and also poetical quality of love, community and Christian responsibility. Some phrases in a communion hymn by Luther (EKG 163) speak of celebrating communion as strengthening believers to live in love and unity. A communion hymn by Andreas Cramer of 1730 develops the idea of communion as the inspiration for true community living, as we are 'eating of one bread and drinking of one cup' and that this should encourage us to live together 'as brothers, strengthening who are bent and protecting the weak' (EKG 159 v. 2). This hymn has never been translated, perhaps because the metre and rhyming pattern are difficult to translate into English, but although it has been sung and loved for centuries, the focus on community is still a relatively minor focus in Lutheran communion hymns, and more hymns speak mainly of the forgiveness of sins.

The other place where Christian service receives some poetically passionate lines is in morning hymns, where God's help is sought for the daily duties, work and service. Here Christian works are not problematised in a theological sense, they are simply there to be done with God's help:

with joy I go my way, my given task fulfilling

with ready hands and willing Thy grace and help my stay. (EKG 341 v. 7, LH 517 v. 5)

\section{Justice, resistance}

A painful realisation for Christians who were involved in the struggle for justice in South Africa was how few hymns there were in traditional hymn books which could provide any kind of support and inspiration. This is true not only of the Lutheran hymn book but across the board. Some people tried to write, but not many of these songs found a wide hearing though some were published in Cry Justice by John de Gruchy (1986). ${ }^{43}$ The problem is not only to write a song about justice, but to write it well enough that it will indeed be sung. Inspiration for resistance is likely to come from biblical traditions of resistance, often found in Psalms and of course the prophetic books. Whilst the Psalms have always been a primary inspiration for Christian hymns, hymns inspired by prophetic traditions are rare. And quite often, the Christianised paraphrases of Hebrew psalms have blunted their original power. This phenomenon would merit a more thorough study on its own.

In general, Lutherans are people who are more likely to pray for the government than to be involved in resistance movements, and this is reflected in their hymn book. The

43.This book published in 1986 brought together songs, prayers, meditations and readings from the South African struggle. There were several traditional choruses, and an expanded version of Kumba yah (p. 78), John Gardner's Who will save our land and people? (174) and several original songs in the vernacular or English, one land and people? (174) and several original songs in the vernacular or English, one
of which was based on Amos 5:24ff and was sung within the Students'Union for of which was based on Amos 5:24ff and was sung within the Students'
Christian Action (SUCA) when I was a member (De Gruchy 1986:234). 
prayer for good government crops up in several places in the hymn book (e.g. EKG 36, 40, 212, 394 and others) ${ }^{44}$ References to a God of justice who is the protector and helper of the poor, oppressed and downtrodden is, in the EKG largely limited to the section with Psalm paraphrases (EKG 176-200). The final hymn in this section is a paraphrase of the Magnificat, Luke 1, (EKG 200), but the poetic quality falls far below the biblical example and it is very seldom sung (never in my personal experience). ${ }^{45}$ There are several other examples of seldomsung hymns which take up the Psalm references to a God of justice. ${ }^{46}$ The fact that these songs are not so popular is telling in itself. It is not only an issue of poetic quality, but also of content that does not sit so comfortably with congregational culture.

Two hymns which paraphrase with poetic power and have become firm favourites are both paraphrases of Psalm 146. Unfortunately, if quite a lot gets lost from a Psalm in paraphrasing it, even more gets lost in translation. The first by Herrenschmidt 1714 (EKG 198) has been translated and appears in both the American and Australian hymnals. The German paraphrase is fairly close to the Psalm. Verse 3 of Psalm 146: 'Do not put your trust in princes, in mortal men who cannot save ...' is paraphrased as follows (in the translation of the Australian hymnal):

\author{
Trust not in princes who, born of woman \\ are dust and turn to dust always; \\ Vain are their counsels for they are human, \\ and fail when death will claim its prey. \\ Since then no man can help afford, \\ Trust ye in Christ our God and Lord. (LH 450 v. 2)
}

This is a fairly straight translation of the German. Then the two translators make cuts - understandably, as the original has eight verses. So what happens to verse 7 of the Psalm: 'he upholds the cause of the oppressed and gives food to the hungry. The LORD sets prisoners free'?

\section{Herrenschmidt paraphrases (literally):}

If there are some who suffer injustice, the Lord vindicates them. To the hungry he will give the food they need to gain strength for life, those heavily bound he sets free and his grace knows no limits. (EKG 198 v. 5)

The American hymnal cuts this verse completely, leaving the hymn with four verses. The Australian hymnal cuts out the element of justice resulting in the following:
Penitent sinners for mercy crying,
pardon and peace from Him obtain;
ever the wants of the poor supplying,
their faithful God He doth remain.
He helps His children in distress,
Widows bereaved, the fatherless. (LH 450 v. 5)

This is a very interesting shift. Penitent sinners are present neither in the Psalm nor in the German paraphrase. And both

\footnotetext{
44. Benjamin Schmolck's extensive prayer for the country Herr, höre, Herr, erhöre (EKG 394) has one phrase praying for support for the persecuted in verse 10.
}

45.The EG has still included this hymn from 1548 (e.g. 307) but has supplemented it with a more contemporary paraphrase of 1952 , using a tune from the Genevan Psalter. In my experience neither version has been used much.

46.For example, Psalm 68 - EKG 183, Psalm 85 - EKG 185, Psalm 98-EKG 186. those who suffer injustice and the prisoners have disappeared from the translation. This is a very telling shift, which can be traced in many a Psalm paraphrase, which in the end no longer speaks of injustice - a social category - but of sin and moral failings. I will not deny that this happens in many of the German paraphrases too, though this one is true to its source. ${ }^{47}$ Luther himself is very free in his paraphrases. His paraphrase of Psalm 12 leaves out the reference to oppression and focuses on the poor and needy. He contextualises the Psalm to the situation of the persecution of the true gospel teaching (EKG 177). His version of Psalm 67 changes the verse 'for you rule the people justly' (Psalm 67 v. 4) to 'You are the judge on earth, and do not allow sin to reign' (own translation EKG 182 v. 2). Whilst I am generally in favour of free paraphrases of the Psalms, rather than the often stilted literal ones, there needs to be awareness of the important themes that are not entering Christian theology.

The other paraphrase of Psalm 146 in the EKG, the one by Paul Gerhardt, was never translated. Apparently even in German it gained popularity rather late. The reason may be its content, but also the exuberant tune, which admittedly is not that easy to sing. It is a much freer paraphrase of the Psalm, and leaves out the reference to the princes. But it retains the focus on the God who cares for the poor, upholds the cause of the oppressed and liberates the captives. I give here my own translation of a verse - also relatively free, as I condensed 8 verses into 5:

He hears us when we call Him, and rescues us from need.

He cares and nurtures daily, the hungry He will feed.

Protects the weak who suffer oppression, violence, pain,

those who in bondage languish, He will set free again. (WS 381 v. 4)

The two hymns discussed here speak of the God of justice acting on behalf of the oppressed. They say nothing about our own role in this, and this would also have been to go beyond what the Psalm itself says. But in general the hymnal is silent on our responsibility to stand up to injustice and help those suffering oppression. Helping the poor from our bounty is still in order. But naming injustice means criticising those in power. Calling for the release of captives, means saying those who put them there were in the wrong. And confronting the authorities is something we do not have a strong tradition about. During the apartheid years, Lutherans who opposed apartheid received some of their strongest attacks from other Lutherans. Unfortunately our hymn book did not help much there. The biblical traditions that we could draw on were not reflected in the hymn book. To go back to the original image of the sun and moon - we were living with the light of the half-moon and taking that as the full criterion of truth.

The German Lutheran hymnal of the early 1990s, which we are using today fortunately went some steps towards rectifying this major gap and has a whole section on hymns about justice, peace and the integrity of creation (EG 421-436). ${ }^{48}$

47.In the Psalm 68 paraphrase of Matthias Jorissen 1793, the references to widows and orphans and prisoners in verse 6 is included at the end of Verse 4 with the words 'how tenderly he loves his people, giving the weak strength and power' (EKG 183 v. 4).

48.Most of these songs come from the anti-nuclear peace movement. There are fewer that speak convincingly about social justice. 


\section{Conclusions}

Lutheran hymn singing tradition shaped our identity, and the self-definition of Lutheran congregations in turn shaped the hymn books. Songs with more critical content were often ignored, not so often sung, and then had the tendency to drop out of hymn books. Hymns that had staying power were powerful hymns of faith, hope and trust, but with a comfortable personal morality and social ethics restricted to doing my Christian duty and obeying and praying for the government. There were some critical elements which were introduced into the EKG, which was a post World War II hymn book, but these initially had a muted impact on our South African German communities. In general, the spirituality which defines most of the traditional Lutheran hymns is still dominant in our congregations. But there is a growing openness to more socially critical content, which has been introduced in the new German hymnal. Nevertheless, hymns that speak of Christian responsibility with the same passion and poetic power than they do of faith and trust, are still relatively rare.

As I said, whilst hymnals have a much wider spread of themes than contemporary song books, each hymnal commission still has its blind spots, and there is a limit to how many of the not so popular songs a hymnal can include, simply to ensure a theological spread of themes. It is up to the next generation of song writers to try to fill the gaps with songs of poetic and musical power.

\section{Acknowledgements Competing interests}

The author declares that she has no financial or personal relationship(s) which may have inappropriately influenced her in writing this article.

\section{References}

\section{Hymnals and Song Books}

CAH Moore, G. (ed.), 2000, Complete Anglican Hymns Old and New, Kevin Mayhew, Suffolk.

EG EKD, 1995 Evangelisches Gesangbuch (Stammausgabe) Biblia-Druck, Stuttgart.
EKG Ev.Luth Kirche Niedersachen, 1974 Evangelisches Kirchengesangbuch, Schlütersche Verlagsanstalt, Hannover.

ELW Evangelical Lutheran Church in America 2006, Evangelical Lutheran Worship, Fortress Publishers, Augsburg.

GMH Niemeyer, E. (ed.), 1925, Große Missionsharfe - Erster Band, Bertelsmann, Gütersloh.

KMH Bertelsmann, D., 1919, Kleine Missionsharfe im Kirchen und Volkston, 79. Auflage, Bertelsmann, Gütersloh.

LBW Inter-Lutheran Commission on Worship, 1978, Lutheran Book of Worship, Augsburg Publishing House, Minneapolis.

LH Lutheran Church of Australia, 1995, Lutheran Hymnal with Supplement, Openbook Publishers, Aidelaide.

MP Horrobin, P. \& Leavers, G., 1990, Mission Praise - Combined Music Edition, Marshall Pickering, London. PMCid:1663822

SF Coltman, N. \& Townend, S. (eds.), 1991, Songs of Fellowship - Music Edition, Kingsway Music, Eastbourne.

WS Tönsing, G. (ed.), We sing of Your Love, unpublished song collection.

\section{Books and articles}

Albrecht, C., 1995, Einführung in die Hymnologie, Vandenhoek \& Ruprecht, Göttingen. Bieritz, K-H. \& Ulrich, M., 1985, Gottesdienstgestaltung, Vandenhoek \& Ruprecht, Göttingen.

Craig-Wild, P., 2002, Tools for transformation: Making worship work, Darton, Longman \& Todd, London.

De Gruchy, J., 1986, Cry justice! Prayers, meditations and readings from South Africa, Collins Liturgical Publications, London.

Dietz, O., 1989, Unser Gottesdienst, Claudius Verlag, München. PMCid:1451279

Klek, K. 2008, “'So nimm denn meine Hände ...": Rehabilitation des Gefühls im Evangelischen Gesangbuch mit Liedern aus dem 19. Jahrhundert?', Arbeitsstelle Gottesdienst: Zeitschrift der GAGF 22(3), 39-43.

Leith, J.H., 1981, An introduction to the reformed tradition, Atlanta, John Knox Press.

Lieberknecht, U., 1994, Gemeindelieder: Probleme und Chancen einer kirchlichen Lebensäußerung, Vandenhoek \& Ruprecht, Göttingen.

Luther, M., [1518] 1957, 'Heidelberg disputation', in H. Grimm (ed.), Luther's Works, vol. 31, pp. 39-70, Muhlenberg Press, Philadelphia.

Luther, M., [1521] 1963, 'Letter to Melanchton' Letter No. 91 in G. Krodel (ed.), Luther's Works, vol. 48, pp. 277-282, Fortress Press, Philadelphia.

Luther, M., [1523] 1972a, 'Letter to George Spalatin', in G. Krodel (ed.) Luther's Works, vol. 49 pp 68-70, Fortress Press, Philadelphia,

Luther, M., [1520] 1972b, 'On the Freedom of the Christian', in G. Krodel (ed.), Luther's Works, vol. 31, pp. 327-378, Muhlenberg Press, Philadelphia .

Nüchtern, M., 2008, “'Holder Knabe im lockigen Haar”- oder: Ein bisschen Kitsch darf sein', Arbeitsstelle Gottesdienst: Zeitschrift der GAGF 22(3), 5-15.

Rößler, M., 1990, Liedermacher im Gesangbuch, Band I, Calwer Verlag, Stuttgart.

Routley, E., 1983, Christian hymns observed, Alden Press, Oxford.

Schmidt-Lauber, H-C. \& Seitz, M., 1992, Der Gottesdienst: Grundlagen und Predigthilfen zu den liturgischen Stücken, Calwer Verlag, Stuttgart.

Thompson, B., 1961, Liturgies of the Western Church, Fortress, Philadelphia.

Tönsing, G., 2008, 'A Lutheran Critique of Popular "Praise and Worship" Songs', in K. Bloomquist (ed.), Lutherans Respond to Pentecostalism, pp. 99-116, Lutheran University Press, LWF Publications, Minneapolis.

Tönsing, G., 2011, 'The space to create and the space to participate. A critical look at contemporary worship songs', paper presented at Practical Theology Conference, Unisa, Pretoria, January 2011. 